\title{
Study of the Effect on the Quality Attributes of Apple Pomace Powder Prepared by Two Different Dryers
}

\author{
Rohit Rawal ${ }^{1}$, Dorcus Masih ${ }^{2}$ \\ I (M.Tech Food Technology Student, Department of Food Process Engineering, Vaugh School of Agricultural \\ Engineering and Technology, Sam Higginbottom Institute of Agriculture, Technology and Sciences, (Deemed- \\ to-be University), Allahabad-211 007, UP, India) \\ ${ }^{2}$ Assistant Professor, Department of Food Process Engineering, Vaugh School of Agricultural Engineering and \\ Technology, Sam Higginbottom Institute of Agriculture, Technology and Sciences, (Deemed-to-be University), \\ Allahabad-211 007, U P, India)
}

\begin{abstract}
Industrialization of horticulture sector no doubt assured economic prosperity but brought along with it a huge quantity of fruit processing waste, whose disposal in the environment caused not only extensive pollution but also the loss of natural wealth. Apple pomace is a left-over residue after apple juice extraction amounting to about 20-30 per cent of the total processed apple fruits. To utilize this waste, a study of the effect on the quality attributes of apple pomace powder prepared by two different dryers was carried. Apples were blanched to get wet apple pomace cake which was exposed to different drying air temperatures $\left(60,70,80^{\circ} \mathrm{C}\right.$ and solar dryer) with different tray dryer $(40,50 \mathrm{~g}$ and $60 \mathrm{~g})$ Initial moisture content of the apple pomace was an average of $442.49 \%$ d.b. Drying of apple pomace took place in falling rate period. Overall drying rate linearly increased with temperature and decreased with increase in tray dryer at all temperatures. In solar dryer it takes time and depends on the condition of the weather. Nutritional evaluation was done for crude fibers, fat and protein for apple pomace dried powder. The temperature of $70^{\circ} \mathrm{C}$ and tray dryer of $50 \mathrm{~g}$ yielded the highest values of protein as well as fiber content. It was concluded that apple pomace should not be dried at temperatures more than $70{ }^{\circ} \mathrm{C}$ as at high temperature, significant reduction of protein and sugar content was observed. Medium temperature $\left(60-70^{\circ} \mathrm{C}\right)$ should be used for drying and quality of pomace powder is better than solar dryer. Shelf life of the apple pomace powder is long for $80^{\circ} \mathrm{C}$ due to very less moisture and it is very short for solar dryer due to presence of high moisture.
\end{abstract}

Keywords: Solar dryer, Tray dryer, Apple pomace, Physico-chemical study, Shelflife.

\section{Introduction}

Nowadays, there is great political and social pressure to reduce the pollution arising from industrial activities. Almost all developed and underdeveloped countries are trying to adapt to this reality by modifying their processes so that their residues can be recycled. Consequently, most large companies no longer consider residues as waste, but as a raw material for other processes. Most by-product feedstuffs (BPF) result from the processing of commercial crops, the food processing industry and the fibre industry $[\mathbf{1}, \mathbf{2}, \mathbf{3}]$. The Apple is the pomaceous fruit of the apple tree, species Malus domestica in the rose family (Rosaceae). It is one of the most widely cultivated tree fruits, and the most widely known of the many members of genus Malus that are used by humans. Apples grow on small, deciduous trees. The tree originated in Central Asia, where its wild ancestor, Malus sieversii, is still found today. Apples are the most favoured fruit of millions of people and are a widely grown fruit in temperate regions of the globe. Apple is the one of the important fruit crops known to mankind and is produced all over the world in the temperate climate. In India, where it is grown in the northern states including Himachal Pradesh and Jammu and Kashmir and Kashmir where large scale apple processing plants are located [4].

Many agricultural and agro-industrial by-products that could profitably be used are available locally but are no fully exploited for the feeding of livestock. Such feedstuffs include fibrous by-products such as wheat bran, maize bran, rice bran, tomato pomace, grape pomace, sugar beet pulp, pomegranate pulp and apple pomace [5]. This agro-industrial by products, although containing potentially toxic components, can be improved by various treatments such as chemical, mechanical, pelleting, grinding and other processing techniques. Many by-products have a substantial potential value as animal feedstuffs. The utilization of agroindustrial by products may be economically worthwhile, since conventional feedstuffs are often expensive. Several factors have lead to increase interest in by-product feedstuffs, such as pollution abatement and regulations, increasing costs of waste disposal and changes in perception of the value of byproduct feedstuffs as economical feed alternatives $[\mathbf{6}, \mathbf{7}, \mathbf{8}]$.

Apple pomace, a by-product of juice or puree making industry, is a rich source of many nutrients including carbohydrates, minerals, except protein, and in Iran, production of this by product exceeds 97,000 tons 
/ year. Apple pomace has been utilized as animal feed after ensiling or after drying. Rumsey and Lindahl showed that a diet consisting primarily of urea supplemented [9].

The composition of apple pomace with respect to its fiber content viz sugar, cellulose, hemicelluloses, pectin and roughage appears to have the best proposition for incorporation in the bakery industry for production of high fibre baked foods. The crude fibre content of apple pomace is approximately $14-30 \%$ of the dry weights. Apple fibre is higher in TDF (Total Dietary Fibres) than wheat and oat bran. It has good water holding capacity and act as humectants in certain food products [10].

Apple fibre has been incorporated into cookies, granola bars and muffins to produce high fibre bakery products. Use of apple pomace has been made through fermentation into several product including citric acid, ethanol, pigment etc. The most promising method for complete utilization of apple pomace may be through solid state fermentation with yeasts, separating out ethanol and using the left over protein rich material after drying as an animal feed. The increasing demand for ethanol for various industrial solvents, cleansing agent, and preservatives has necessitated increased production of this alcohol.

Drying of the apple pomace seems to be a promising utilization way for animal feed or for further processing such as nutrient recovery. Drying of moist materials is a process involving heat and mass transfer simultaneously. Drying techniques have been used for centuries, undergoing important evolutions. Studies on the drying processes are numerous because it is one of the most common industrial operations and involves high energy consumption, $10-25 \%$ of the total energy used in manufacturing processes worldwide [11].

Several experimental studies on the drying characteristics of apple products have been conducted such as apple slices apple cubes. Apple puree, cylindrical shaped apple lump, and rectangular shaped apple lump. Apple pomace was, however, only used as a test material to compare two moisture determination methods, i.e., infrared drying technique and conventional oven technique. So far, there is little information available about drying characteristics of apple pomace. Therefore, study on drying of apple pomace is of great significance for environment protection and resource utilization $[4,6, \mathbf{6 0}]$.

Since, apple pomace is a part of fruit; it has potential for conversion into edible products. Hence, the current problem was selected to conduct studies on the drying characteristics of apple pomace and find out thr best results by drying apple pomace in tray dryer and solar dryer.

\section{Historical Background}

Drying of the apple pomace seems to be a promising utilization way for animal feed or for further processing such as nutrient recovery. Drying of moist materials is a process involving heat and mass transfers simultaneously $[9, \mathbf{1 3}, \mathbf{1 4}]$. Drying techniques have been used for centuries, undergoing important evolutions [15]. Studies on the drying processes are numerous because it is one of the most common industrial operations and involves high energy consumption, $10-25 \%$ of the total energy used in manufacturing processes worldwide $[16,17]$.

Several experimental studies on the drying characteristics of apple products have been conducted such as apple slices $[\mathbf{1}, \mathbf{3}, \mathbf{5}, \mathbf{6}, \mathbf{8}, \mathbf{9}, \mathbf{1 2}, \mathbf{1 6}, \mathbf{1 8}]$, apple cubes $[\mathbf{1 5}, \mathbf{1 7}]$ apple puree $[\mathbf{3 , 5}, \mathbf{8}]$ cylindrical shaped apple lump $[7,10,11,12,13,15]$ and rectangular shaped apple lump $[5,9,12,17,18]$. Apple pomace was, however, only used as a test material to compare two moisture determination methods, i.e., infrared drying technique and conventional oven technique (Fenton and Kennedy, 1998). So far, there is little information available about drying characteristics of apple pomace. Therefore, study on drying of apple pomace is of great significance for environment protection and resource utilization.

\section{Materials and Methods}

Cull apples of red delicious variety were procured from local market of Allahabad, India and thoroughly cleaned with potassium permanganate solution to remove any kind of infections and then washed with tap water to remove soil and dust particles $[\mathbf{2 , 3 , 1 2 , 1 4 , 1 5 ]}$. Washed apples were sliced into four equal parts and cored $[\mathbf{1 6}, \mathbf{1 8}]$. The apple slices were blanched with potassium metabisluphite solution for fifteen min at the rate of $100 \mathrm{mg}$ per liter of solution in one kilogram of apples. After blanching, the sliced apples were crushed in a fruit crusher and apple juice was removed through muslin cloth manually and pomace was obtained for further processing.

\subsection{Drying of Apple Pomace}

In this paper two dryers were used for reducing the water contents in the pomace and also analyzing the effect of temperature on the pomace so the two dryers were
a. Tray drier
b. Solar dryer 


\subsubsection{Solar Dryer}

The introduction of low cost and locally manufactured $[1,10,18,19,20]$ solar dryers offers a promising alternative to reduce the tremendous postharvest losses. The objective of a dryer is to supply the product with more heat than is available under ambient conditions, thereby increasing sufficiently the vapour pressure of the moisture held within the crop and decreasing significantly the relative humidity of the drying air and thereby increasing its moisture carrying capacity and ensuring sufficiently low equilibrium moisture content. One type of solar dryer is shown in $[21,22,23]$ and also shows the working of solar dryer. It was designed for the particular requirements of pomace powder but the principles hold for other products and design types, since the basic need to remove water is the same. Warm air can hold more moisture than cold air, so the amount required depends on the temperature to which it is heated in the collector as well as the amount held (absolute humidity) when it entered the collector. The way in which the moisture absorption capability of air is affected by its initial humidity and by the temperature to which it is subsequently heated.

\subsubsection{Tray Dryer}

The Tray Dryer is a conventional drying machine suitable for drying of powders, granules, and similar other materials. The dryer is ideally suited for use for drying powders, pigments, plastic granules, agricultural products like drying chillies, species, papad, potato, chips, onions, fish, garlic, Grapes, cashew nuts, confectionery, macaroni, wood etc. The dryer is made out of angle frame; doubled walled from CRCA mild steel, thermally insulated with 3 inch thick glass wool between the walls .Inner body is finished with heat resistant aluminium paint, outside in grey hammer tone. The dryer is electrically heated with sheathed tubular heaters and fitted with fan run by belt drive unit or steam heated with digital temperature control.

\subsection{Experimental Plan}

Experimental plan for the making of apple pomace powder are described in the table 1 and the Fig. 2 which is the flow chart of the drying of apple pomace.

Table 1: Description of contents of Sample

\begin{tabular}{|l|l|l|}
\hline Parameters & Description & Levels \\
\hline Apple pomace & Fresh & 1 \\
\hline Sample size & $250 \mathrm{~g}$ & 1 \\
\hline Pretreatments & No Treatments & 0 \\
\hline Drying methods & Solar dryer & 1 \\
& Tray dryer & 1 \\
\hline Drying temperature & $60,70,80^{\circ} \mathrm{C}$ & 3 \\
\hline Replication & & 3 \\
\hline
\end{tabular}

3.3 Drying characteristics

3.3.1Drying rate

Drying rate measures the rate of existence of moisture content from the Apple. The measurements for the moisture are mathematically calculated by different formulas [18, 19, 23].

$$
\begin{aligned}
& \text { Present moisture content }=\frac{\text { Loss in weight }}{\text { Initial Weight of the sample }} \times 100 \\
& \text { Moisture content(M. C. })(\text { wet basis })=\left(\mathrm{M}_{1}-\mathrm{M}_{2}\right) /\left(\mathrm{M}_{1}\right) \times 100 \\
& \text { Moisture content(Dry basis) }=\frac{\text { M. C. }(\text { wet basis })}{100-\text { M. C. }(\text { wet basis })} \times 100 \\
& \text { MC }(\text { lost })=(\text { M. C. }(\text { current })-\text { M. C. (previous) }) \\
& \text { Rate of drying }=(\text { MC }(\text { lost })) /(\text { time difference }) \times 100
\end{aligned}
$$

M.C. $=$ moisture content of the sample ( $\%$ w.b. and d. b.)

$\mathrm{M}_{1}=$ wt. of the sample before solar dryer $(\mathrm{g})$.

$\mathrm{M}_{2}=$ wt. of the sample after solar dryer $(\mathrm{g})$.

Moisture content of sample during drying

Moisture content of the sample during dying was computed through mass balance. For this purpose, weight of the sample during was recorded every 30 balance mint.

The following formula was used to calculate the moisture content:

Where,

$$
\text { M. C. }=\frac{(\text { Wt. of the sample at desired time })-(\text { wt. of bone dry material })}{(\text { Wt. of sample at any time })} \times 100
$$




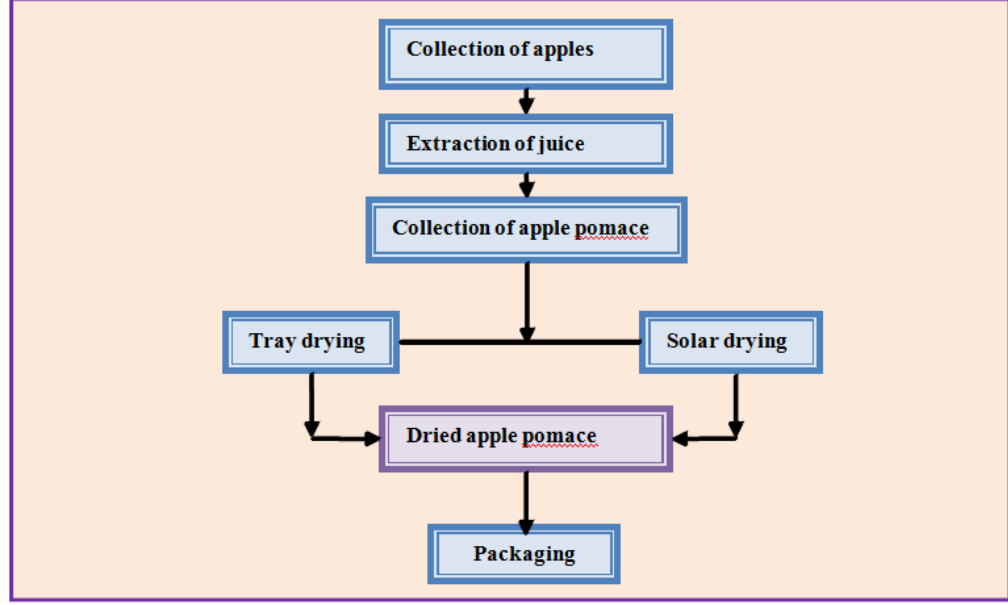

Fig. 2: Process flow chart of apple pomace drying.

$$
\text { Wt. of born dried }=\frac{(\text { Initial wt. of the sample } \times 100)-(\text { Initial M. C. })}{(100)}
$$

\subsubsection{Dehydration ratio}

Dehydration ratio is an important factor, which shown bulk reduced in weight of the sample. Moist the dehydration ratio better the process of drying. Formula used for calculating dehydration ratio is:

$$
\text { Dehydration ratio }=\frac{(\text { Initial weight of the product })}{\text { (Weight of dehydration product })}
$$

\subsubsection{Rehydration ratio}

Rehydration ratio is one of the important bases to form a base material for further utilization. Rehydration is the replace of water in development food. Fruits are rehydration to study the reconstitute of dried sample. Rehydration ratio show the originality grained and acceptability attribute of a product $[\mathbf{1 , 9 , 2 2 , 2 3 ]}$.

Where,

$$
\text { Rehydration ratio }=\frac{\left(\text { Weight of the socked product }\left(\mathrm{W}_{\mathrm{r}}\right)\right)}{\left(\text { Weight of dehydration product }\left(\mathrm{W}_{\mathrm{d}}\right)\right)}
$$

$\mathrm{W} \mathrm{r}=$ weight of the soaked product.

$\mathrm{W} \mathrm{d}=$ weight of the dehydration product.

3.4 Physicochemical analysis.

3.4.2 Protein content:

It will be analysed by knowing the Nitrogen content by Kjeldahl (AOAC 2000).

\subsubsection{Dietary fibre:}

Dietary fibre is catogersied in soluble and insoluble dietary fibre and will be estimated by AOAC 993.19 and AOAC 991.42 method respectively.

\subsection{Statistical Analysis}

Data obtained from the chemical analysis and physicochemical properties was subjected to analysis of variance technology two way classification, and critical different will be used to determine best treatment. Completely randomized design (CRD) will be used to know the significant different between treatment of product regarding the attributes. Calculated a value will be compound with a table value of $\mathrm{F}$ at $5 \%$ level of signification. If calculated value will be the table effect will be considered to be significance of study will be tested at 5\% level (Kumar and Kumar, 2011).

$$
\begin{array}{lll}
\mathrm{t} & \left.=\sqrt{(n-2)} / \sqrt{\left(1-1 / 2^{2}\right.}\right) \\
\mathrm{S} . E d . & =\sqrt{2} \mathrm{MESS} / \mathrm{r} \times \mathrm{t} \times \mathrm{s} \\
\mathrm{C} . \mathrm{D}= & \mathrm{S} . \mathrm{Ed} \times \mathrm{t} 5 \% \text { at e. d. f. } \\
\text { Where, } & \\
\mathrm{t} & =\quad \text { distribution of observation } \\
\mathrm{r} & = & \text { co-efficient of correlation } \\
\mathrm{n} & = & \text { no. of observation } \\
\text { S.Ed. } & = & \text { standard error of difference }
\end{array}
$$




$\begin{array}{lll}\text { e.d.f. } & = & \text { error of degree of freedom } \\ \text { C.D. } & =\quad \text { critical difference } \\ \text { MESS } & =\quad \text { error mean sum of square }\end{array}$

\section{Results and Discussion}

Studies on quality were based on physicochemical analysis (i.e. moisture, fat, protein, ash and fibers) and sensory properties, which were determined for developed incorporated pomace powder, were influenced by packaging material, storage of environmental condition and chemical constituents of the product. Apple pomace powder was packed in LDPE bags and stored at room temperature. The shelf life studies were conducted at the interval of 15 days up to 45 days.

\subsection{Drying characteristics of Apple Poamce Powder}

\subsubsection{Drying rate}

Moisture content of the apple pomace is removed with the time in the tray dryer. Drying rate at 60,70 , $80^{\circ} \mathrm{C}$ of tray dryer is $1.66,2.21,2.89$ and solar dryer is 0.021 . Hence the rate of drying is higher at higher temperature i.e. $80^{\circ} \mathrm{C}$ Drying rate of solar dryer is very slow because it on the sun light and that's why it takes long time.

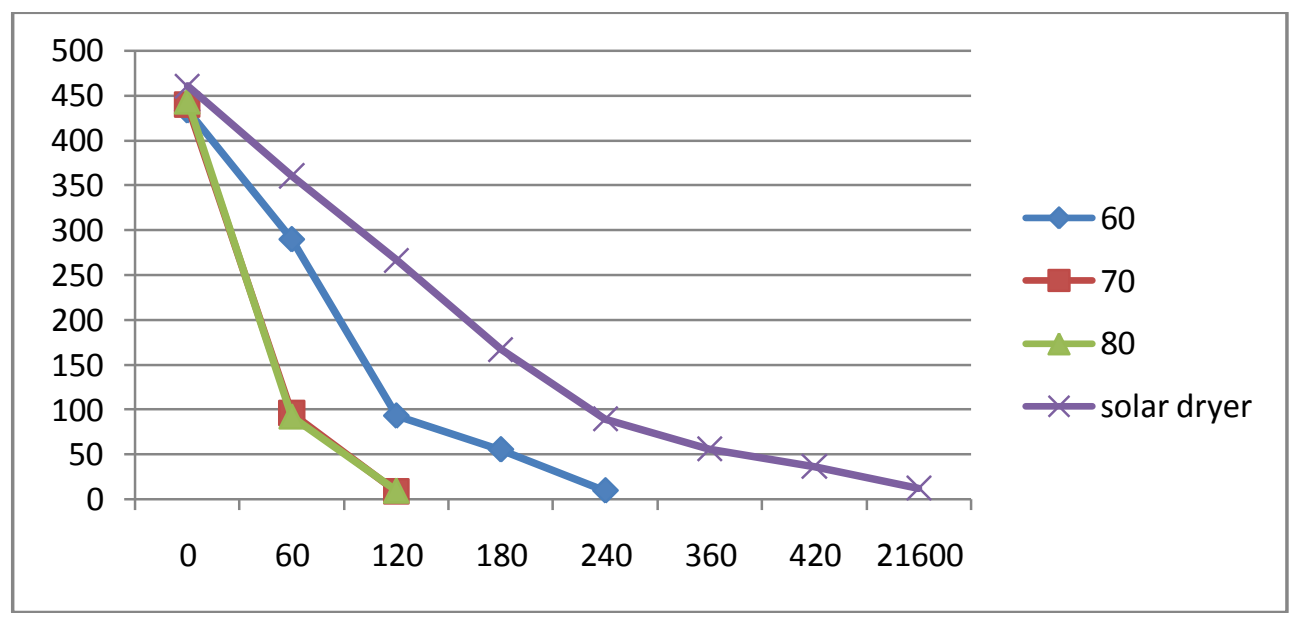

Fig. 3 Change in moisture content with time

\subsubsection{Drying Characteristics of Tray Dryer}

The initial moisture content of apple pomace was in the range of 433.72 to $463.73 \%$ d.b. The moisture content of the apple pomace decreased with drying time for all conditions of temperature and tray load. However, the drying time varied with the conditions of drying which ranged from 150 to 420 min, being lower at higher drying temperature (Table 4.1).

Table 4.1: Drying data for apple pomace

\begin{tabular}{|l|l|l|l|l|l|}
\hline $\begin{array}{l}\text { Drying } \\
\text { Temperature } \\
\left({ }^{\mathrm{O}} \mathrm{C}\right)\end{array}$ & $\begin{array}{l}\text { Tray load } \\
\left(\mathrm{g} / 0.006 \mathrm{~m}^{2}\right)\end{array}$ & Mo (\% d.b.) & MF (\% d.b.) & $\begin{array}{l}\text { Drying time t } \\
(\mathrm{min})\end{array}$ \\
\hline 60 & 40 & 433.72 & $\begin{array}{l}\text { Drying Rate } \\
(\% \mathrm{db} / \mathrm{min})\end{array}$ \\
\hline & 50 & 436.72 & 9.80 & 255 & 1.88 \\
\hline & 60 & 434.94 & 9.20 & 300 & 1.42 \\
\hline 70 & 40 & 439.57 & 8.05 & 420 & 1.01 \\
\hline & 50 & 438.24 & 8.80 & 195 & 2.20 \\
\hline & 60 & 443.61 & 8.95 & 330 & 1.81 \\
\hline 80 & 40 & 448.62 & 9.61 & 150 & 1.30 \\
\hline & 50 & 463.74 & 9.61 & 195 & 2.89 \\
\hline & 60 & 460.33 & 9.67 & 225 \\
\hline Solar Dryer & & 12.67 & 21600 \\
\hline
\end{tabular}

The average drying rate represents the cumulative rate of drying from time $t=0$ to any selected drying time $\mathrm{t}$ which was affected by temperature and tray load. The average drying rate was higher at higher temperature and decreased with the drying time. Effect of tray dryer on average drying rate of $40 \mathrm{~g}$ was higher than $50 \mathrm{~g}$ and then the $60 \mathrm{~g}$ for all the experimental temperatures. 


\subsubsection{Drying characteristics of Solar Dryer}

In the solar dryer the rate of the reduction of the percentage of moisture content is depends on the sun rays. It required much time for the drying of the apple pomace. So the pomace left in the solar dryer up to 15 days and approximate temperature of it is about $55^{\circ} \mathrm{C}$ and taking readings of the pomace every day. After the observation, the results of the moisture contents from starting day to $15^{\text {th }}$ day shown in table 4.1. The results show that apple pomace dried by solar dryer have much more moisture content than tray dryer and drying rate is very less.

\subsubsection{Dehydration and Rehydration ratio}

Dehydration ratio is an important factor, which shown bulk reduced in weight of the sample. Moist the dehydration ratio better the process of drying. Hence using above formula of dehydration ratio, the dehydration ratio is $7: 1$ and rehydration ratio is one of the important bases to form a base material for further utilization. Rehydration is the replace of water in development food. Fruits are rehydration to study the reconstitute of dried sample. Rehydration ratio show the originality grained and acceptability of a product. Hence the rehydration ratio is calculated using above formula we get 6:1.

\subsection{Study of Apple Pomace Powder}

4.2.1 Proximate Composition of Apple Pomace Powder

Proximate composition generally represents the nutritional quality of product. It is necessary to observe the proximate composition of apple pomace powder so as to judge the effect on final product after utilization as a novel ingredient. The proximate composition of apple pomace powder was determined and presented in following. Each value represents the average of five determinations.

The protein, crude fat and crude fibre of apple pomace powder was observed to be $7.0 \%, 1.2 \%$, and $1.6 \%$ respectively. On the basis of observed results it could be concluded that apple pomace powder contains significantly higher amount of protein content which justifies the suitability of utilization of apple pomace powder as a functional ingredient in formulation of food products to improve its nutritional characteristics. Similar observations have been reported by (Andres et al. 2004).

Table 4.2 Proximate Composition of Apple Pomace Powder

\begin{tabular}{|l|l|c|}
\hline Sr. No. & Chemical Parameters & Mean value \\
\hline 1. & Moisture (\%) & $5.1 \%$ \\
\hline 2. & Ash (\%) & $1.5 \%$ \\
\hline 3. & Total Protein (\%) & $7.0 \%$ \\
\hline 4. & Crude fat (\%) & $1.2 \%$ \\
\hline 5. & Crude fiber (\%) & $1.6 \%$ \\
\hline
\end{tabular}

\subsubsection{Physico - Chemical Parameters of the Apple Pomace Powder}

Physical parameters of the pomace powder made by solar dryer and tray dryer are shown in the Table 2 In the solar dryer the piece of the apple placed for $360 \mathrm{hrs}$ which work near about $60^{\circ} \mathrm{C}$ and in the tray dryer we use three different temperatures which are $60^{\circ} \mathrm{C}(\mathrm{T} 1), 70^{\circ} \mathrm{C}(\mathrm{T} 2)$ for $3^{1} / 2$ hrs and $80^{\circ} \mathrm{C}(\mathrm{T} 3)$ for $2^{1} / 2$ hrs and make pomace powder from the content of apple from different dryer and different temperature. So the different parameters of the physical and chemical are explain below.

\subsubsection{Physical Parameters}

Apple pomace powder made by different dryer has many physical properties such as their densities (loose and packed), water holding capacity and colours. The densities of the powder reduced when the dryer temperature increases but water absorption capacity increases when temperature increases. All the physical properties are shown in the table 4.4 and Fig 4.1.

Table 3 Physical Property of Apple Pomace powder

\begin{tabular}{|l|l|l|l|l|l|}
\hline Sr. No. & Properties & $\mathbf{6 0}^{\mathbf{0}} \mathbf{C}(\mathbf{T 1})$ & $\mathbf{7 0}^{\mathbf{}} \mathbf{C}(\mathbf{T} \mathbf{2})$ & $\mathbf{8 0}^{\mathbf{}} \mathbf{C}(\mathbf{T 3})$ & Solar Dryer \\
\hline $\mathbf{1}$ & WHC & 9.36 & 9.45 & 9.55 & 9.29 \\
\hline $\mathbf{2}$ & Loose Density & 0.46 & 0.43 & 0.39 & 0.47 \\
\hline $\mathbf{3}$ & Pack Density & 0.66 & 0.61 & 0.55 & 0.65 \\
\hline $\mathbf{4}$ & Colour & Light brown & Dark brown & Very dark & Very dark \\
\hline
\end{tabular}

Where WHC is stands for water holding capacity in gram water per gram solid and densities in gram per centimetre cube. 


\subsubsection{Chemical Parameter or Quality Analysis}

During the present investigation it was observed that there was a significant change in the values of protein and fat content. This was because in the present study the formulation was based on different temperature dryer. Apple pomace has higher protein content when apple has dried at lower temperature. The moisture content of apple pomace powder was varies between the ranges of $2.04 \%-2.6 \%$, whereas the ash content of apple pomace powder was between the ranges of $2.1 \%-2.7 \%$. The protein content was between the ranges of $7.67 \%-9.7 \%$ and fat content was between the ranges of $5.6 \%-6.4 \%$ while the crude fibre range from $1.8-2.00$.

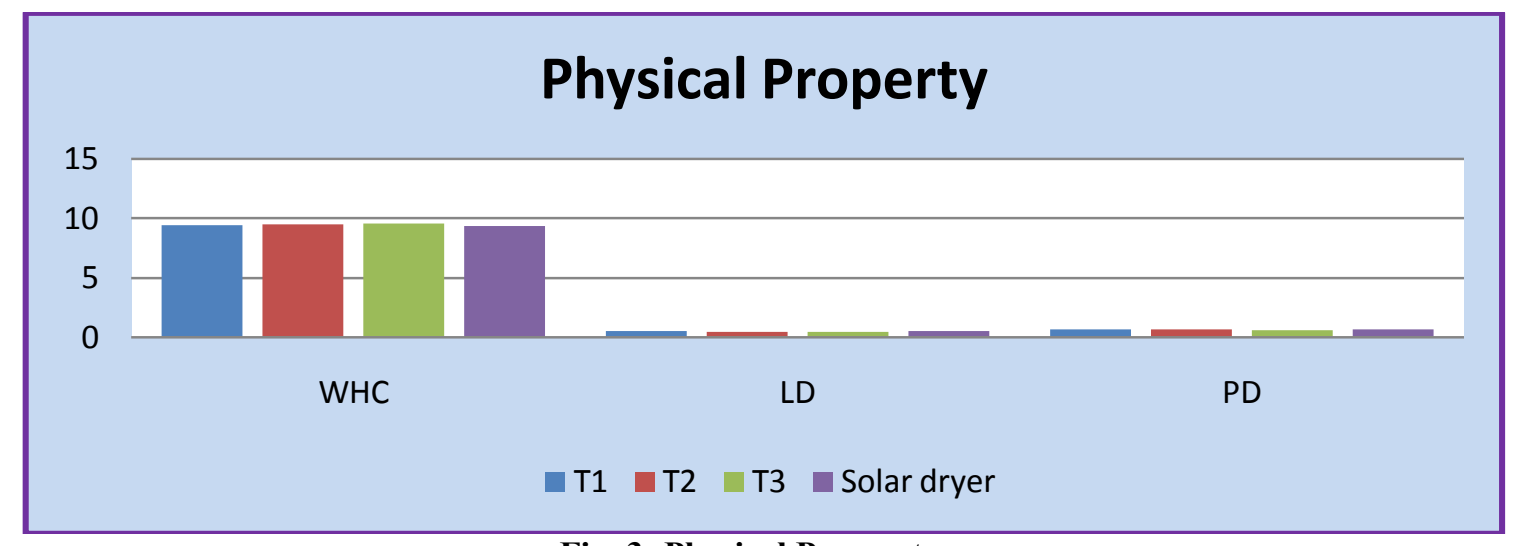

Fig. 3: Physical Parameters

Table 4 Quality analysis

\begin{tabular}{|l|l|l|l|l|l|}
\hline $\begin{array}{l}\text { Dryer } \\
\text { Temperature) } \\
{ }^{0} \mathbf{C}\end{array}$ & Moisture content \% & $\begin{array}{l}\text { Ash content } \\
\%\end{array}$ & $\begin{array}{l}\text { Protein content } \\
\%\end{array}$ & $\begin{array}{l}\text { Crude Fibre } \\
\text { content \% }\end{array}$ & $\begin{array}{l}\text { Fat content } \\
\%\end{array}$ \\
\hline $80^{0}(\mathrm{~T} 3)$ & 2.04 & 2.1 & 7.67 & 1.8 & 5.6 \\
\hline $70^{\circ}(\mathrm{T} 2)$ & 2.31 & 2.3 & 8.43 & 1.9 & 5.8 \\
\hline $60^{\circ}(\mathrm{T} 1)$ & 2.42 & 2.7 & 8.81 & 1.98 & 6.2 \\
\hline Solar & 2.61 & 2.7 & 9.7 & 2.00 & 6.4 \\
\hline
\end{tabular}

A. Quality analysis (\%)

It has been observed that the initial value of all the samples are $2.61 \%, 2.42 \%, 2.31 \%$ and $2.04 \%$ (Solar, $\mathrm{T}_{1}, \mathrm{~T}_{2}$, and $\mathrm{T}_{3}$ ) and after the storage period of 45 days the moisture content observed are $2.98 \%, 2.64 \%$, $2.48 \%$, and $2.24 \%$ (Solar, $\mathrm{T}_{1}, \mathrm{~T}_{2}$, and $\mathrm{T}_{3}$ ). It has been observed that there increase in the moisture content in all the samples. Since, the samples were packed in LDPE from 0 days to 45 days and due to the moisture permeability characteristics of LDPE the graph shows increasing trend in the moisture content of all the samples (as shown in Fig. 4.2). Similar observations have been reported by (Shalini $\boldsymbol{e t}$ al. 2008). The maximum gain in moisture content was observed in sample $\mathrm{T}_{3}$ from $2.08 \%$ to $2.28 \%$. The result of ANOVA table for the analysis of moisture content was carried out $5 \%$ level of significance for 45 days of storage period. The calculated Fvalue was 6206.33 while the tabulated F- value was greater than the tabulated F-value. Thus, there was significant difference between the moisture content of sample. Similarly the result of ANOVA table for Ash, fat, protein, and fiber was carried out $5 \%$ level of significance

For 45 days of storage period. The calculated F- value 309.33, 309.33, 5023.13, \& 6206.33 while the tabulated F- value was $2.95,2.95,4.73 \& 2.95$ it can be inferred that the calculated F- value was greater than the tabulated F- value. 


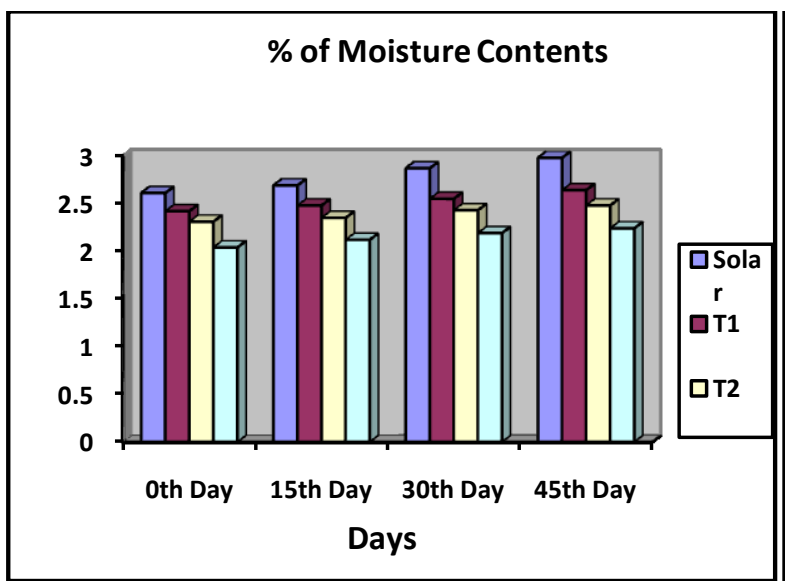

Fig. 4 Moisture Contents

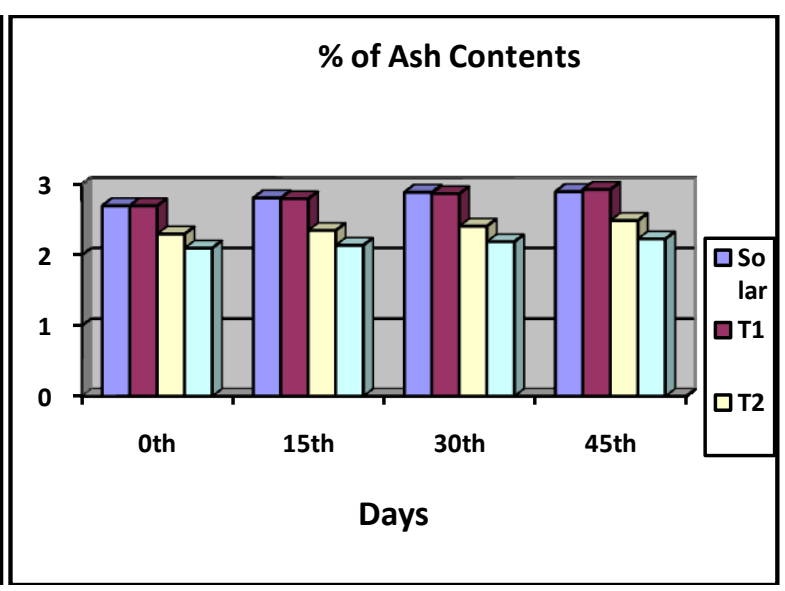

Fig. 5 Ash contents

\subsubsection{Shelf life of apple pomace powder}

Shelf life of the different sample taken for present day, 15 days, 30 days and 45 days and after the observation of physico-chemical properties it found that shelf life of $80^{\circ} \mathrm{C}$ is best among all other on the basis of various physic-chemical properties and the solar dryer sample not best among all various physico- chemical properties due to high moisture content.

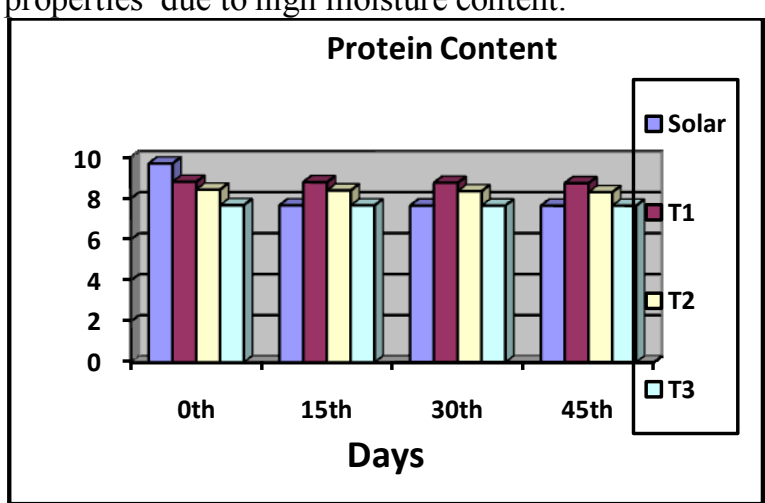

Fig 6 Protein contents

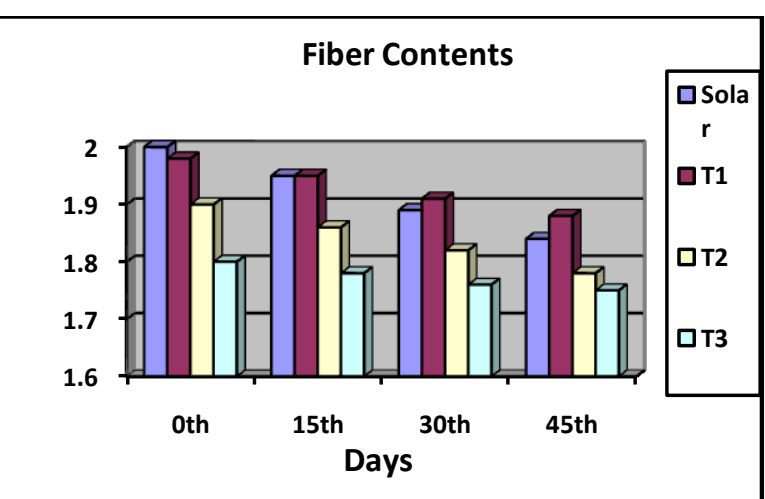

Fig 7 Crude Fiber contents

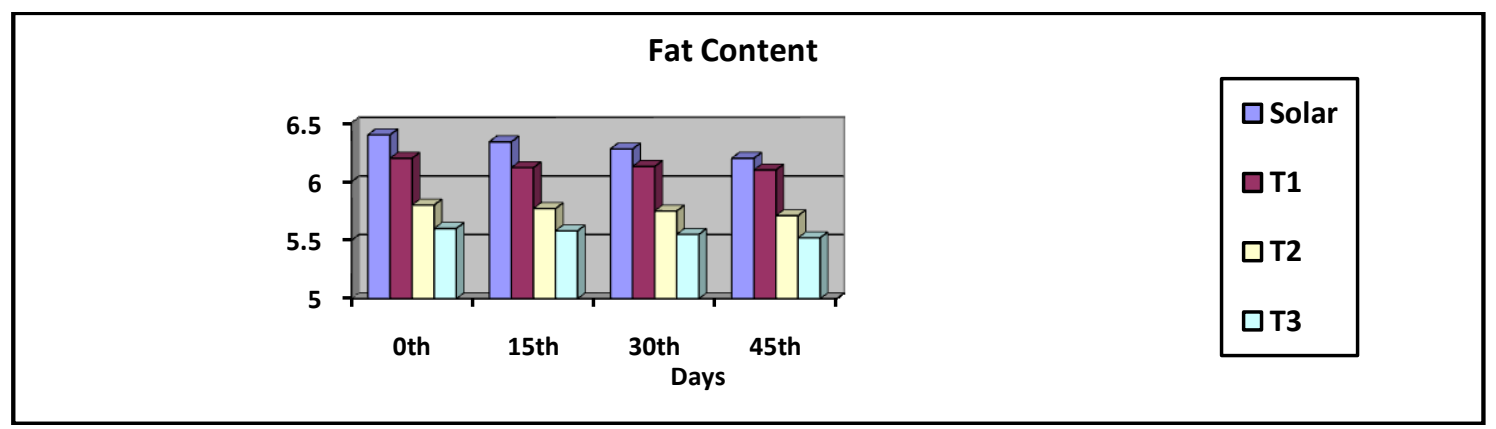

Fig. 8 Fat contents

Table 5 Quality (\%) of Pomace Powder packed in LDPE during 45 days of ambient storage

\begin{tabular}{|c|c|c|c|c|c|c|c|c|c|c|c|c|c|c|c|c|c|c|c|c|}
\hline \multirow{2}{*}{$\begin{array}{l}\text { Treat } \\
\text { ments }\end{array}$} & \multicolumn{5}{|c|}{$0^{\text {th }}$ day } & \multicolumn{5}{|c|}{$15^{\text {th }}$ day } & \multicolumn{5}{|c|}{$30^{\text {th }}$ day } & \multicolumn{5}{|c|}{$45^{\text {th }}$ day } \\
\hline & $\mathbf{M}$ & A & $\mathbf{F}$ & $\mathbf{P}$ & $\begin{array}{l}\mathbf{F} \\
\mathbf{b}\end{array}$ & $\mathbf{M}$ & A & $\mathbf{F}$ & $\mathbf{P}$ & $\begin{array}{l}\mathbf{F} \\
\mathbf{b}\end{array}$ & $\mathbf{M}$ & $\mathbf{A}$ & $\mathbf{F}$ & $\mathbf{P}$ & $\begin{array}{l}\mathbf{F} \\
\mathbf{b}\end{array}$ & $\mathbf{M}$ & $\mathbf{A}$ & F & $\mathbf{P}$ & $\begin{array}{l}\mathbf{F} \\
\mathbf{b}\end{array}$ \\
\hline Solar & $\begin{array}{l}2 . \\
61\end{array}$ & $\begin{array}{l}2 \\
7\end{array}$ & 6 & $\begin{array}{l}9 . \\
7\end{array}$ & $\begin{array}{l}2 . \\
00\end{array}$ & $\begin{array}{l}2 . \\
69\end{array}$ & $\begin{array}{l}2 . \\
81\end{array}$ & $\begin{array}{l}6 . \\
34\end{array}$ & $\begin{array}{l}7 . \\
66\end{array}$ & $\begin{array}{l}1 . \\
95\end{array}$ & $\begin{array}{c}2 . \\
87\end{array}$ & $\begin{array}{l}2 . \\
89\end{array}$ & $\begin{array}{l}6 . \\
28\end{array}$ & $\begin{array}{l}7 . \\
65\end{array}$ & $\begin{array}{l}1 . \\
89\end{array}$ & $\begin{array}{l}2 . \\
98\end{array}$ & $\begin{array}{l}2 . \\
95\end{array}$ & $\begin{array}{l}6 . \\
20\end{array}$ & $\begin{array}{l}7 . \\
64\end{array}$ & $\begin{array}{l}1 . \\
84\end{array}$ \\
\hline T1 & $\begin{array}{l}2 . \\
42\end{array}$ & $\begin{array}{l}2 \\
7\end{array}$ & 6 & $\begin{array}{l}8 . \\
81\end{array}$ & $\begin{array}{l}1 . \\
98\end{array}$ & $\begin{array}{c}2 . \\
48\end{array}$ & $\begin{array}{l}2 . \\
80\end{array}$ & $\begin{array}{l}6 . \\
16\end{array}$ & $\begin{array}{l}8 . \\
79\end{array}$ & $\begin{array}{l}1 . \\
95\end{array}$ & $\begin{array}{l}2 . \\
55\end{array}$ & $\begin{array}{l}2 . \\
87\end{array}$ & $\begin{array}{l}6 . \\
13\end{array}$ & $\begin{array}{l}8 . \\
76\end{array}$ & $\begin{array}{l}1 . \\
91\end{array}$ & $\begin{array}{l}2 . \\
64\end{array}$ & $\begin{array}{l}2 . \\
93\end{array}$ & $\begin{array}{l}6 . \\
10\end{array}$ & $\begin{array}{l}8 . \\
74\end{array}$ & $\begin{array}{l}1 . \\
88\end{array}$ \\
\hline
\end{tabular}




\begin{tabular}{|l|l|l|l|l|l|l|l|l|l|l|l|l|l|l|l|l|l|l|l|l|}
\hline T2 & 2. & 2 & 5 & 8. & 1. & & 2. & 5. & 8. & 1. & & 2. & 5. & 8. & 1. & & 2. & 5. & 8. & 1. \\
& 31 &. &. & 43 & 9 & 2. & 35 & 77 & 39 & 86 & 2. & 41 & 75 & 35 & 82 & 2. & 49 & 71 & 30 & 78 \\
& & 3 & 8 & & & 35 & & & & & 43 & & & & & 48 & & & \\
\hline T3 & 2. & 2 & 5 & 7. & 1. & & 2. & 5. & 7. & 1. & & 2. & 5. & 7. & 1. & & 2. & 5. & 7. & 1. \\
& 04 &. &. & 67 & 8 & 2. & 14 & 58 & 66 & 78 & 2. & 19 & 55 & 65 & 76 & 2. & 23 & 52 & 64 & 75 \\
\end{tabular}

Table 6 Shelf life of apple pomace powder

\begin{tabular}{|l|l|l|}
\hline Sr.no. & Dryer (Temperature) in ${ }^{\mathbf{0}} \mathbf{C}$ & Shelf Life \\
\hline 1 & $\mathbf{8 0}^{\mathbf{0}}$ & Very Long \\
\hline 2 & $\mathbf{7 0}^{\mathbf{0}}$ & Long \\
\hline 3 & $\mathbf{6 0}^{\mathbf{0}}$ & Medium \\
\hline 4 & Solar & Short \\
\hline
\end{tabular}

\subsubsection{Sensory score}

All the sensory evaluation shows in the table and results shows that by drying at $60^{\circ} \mathrm{C}$ gives very fine colour, good taste, aroma, texture and appearance.

Table 7 Sensory evaluation for developed apple pomace powder

\begin{tabular}{|l|l|l|l|l|l|l|l|}
\hline $\begin{array}{l}\text { No. } \\
\text { Treatments }\end{array}$ & Colour & Taste & Aroma & Flavour & Texture & Appearance & O.A.A \\
\hline Solar & 8.5 & 8.33 & 8.33 & 8.33 & 8.33 & 8.5 & 8.33 \\
\hline $60^{\circ}(\mathrm{T} 1)$ & 7.33 & 7.33 & 7.33 & 7.5 & 7.83 & 8.16 & 7.66 \\
\hline $70^{\circ}(\mathrm{T} 2)$ & 7.83 & 7.66 & 7.66 & 8.33 & 8.16 & 8.5 & 8.16 \\
\hline $80^{\circ}(\mathrm{T} 3)$ & 8.66 & 8.83 & 8.16 & 8.66 & 8.33 & 8.66 & 8.83 \\
\hline
\end{tabular}

\section{Conclusion}

From this study it is evidently clear that the apple pomace powder made by tray dryer and solar dryer have good quality and better shelf life but tray dryer have much more quality of product than solar dryer. There was a combined effect of time and temperature on protein content of dried apple pomace powder. The protein content was less at low drying temperature $\left(60^{\circ} \mathrm{C}\right)$ due to prolonged heating than when heated at relatively higher temperature $\left(70^{\circ} \mathrm{C}\right)$ for short duration. High temperature $\left(80^{\circ} \mathrm{C}\right)$ drying also significantly lowered the protein content. Sugar content of apple pomace powder was also affected by temperature and total time taken for heating. It decreased at low temperature $\left(60^{\circ} \mathrm{C}\right)$ drying due to prolonged heating than at relatively higher temperature $\left(70^{\circ} \mathrm{C}\right)$. High temperature $\left(80^{\circ} \mathrm{C}\right)$ drying also significantly lowered the sugar content. After the analysis of the pomace powder results shows that apple pomace powder have lots of ingredients which are very useful for many pupose and all three objectives of this thesis were fulfilled.

\section{References}

[1]. Masoodi F.A., Sharma B., Chauchan G.S (2002) Use of apple pomace as a source of dietary fibre in cakes. Plant Food Human Nutr., 2002,57,121- 128

[2]. M. Kennedy, D. List, Y. Lu, L.Y. Foo, R.H. Newman, I.M. Sims, P.J.S. Bain, B. Halminton, G. Fenton: Apple Pomace and Products Derived from Apple Pomace: Uses, Composition and Analysis. In: Modern Methods of Plant Analysis: Analysis of Plant Waste Materials, H.F. Linskens, J.F. Jackson (Eds.), Springer-Verlag, Berlin, Germany (1999) pp. 75-119..

[3]. Lin K W., and Lin H Y., (2004) Quality characteristics of Chinese-style meatballs containing bacterial cellulose (Nata). Journal of Food Science. 69: 107-111.

[4]. Kaushal, N.K., V.K. Joshi and R.C. Sharma (2002), Effect of stage of apple pomace collection and the treatment on the physicalchemical and sensory qualities of pomace papad (fruit cloth), Journal Food Science Technology, Vol. 39(4), pp. 388 - 393.

[5]. Kinsella.JE(1987). Functional properties of protein: Possible relationship between structure and function in foods. Food chem. 7 (2): $275-288$

[6]. Kumar, N., Sarkar, B.C. \& Sharma, H.K.; "Development and characterization of extruded carrot pomace and rice flour based product", International Journal of Food Engineering, Vol. 6(03), Article 7, 2010

[7]. Kumar, N., Sarkar, B.C. and Sharma, H.K.; "Development and characterization of extruded product using carrot pomace, pulse powder and rice flour", African Journal of Food Science, Vol. 4(11), pp. 703-717, 2010.

[8]. Kumar, N. and Kumar, K.; "Development of Carrot Pomace and Wheat Flour Based Cookies", Journal of Pure and Applied Science and Technology, Vol. 1(1), pp. 5-11, july 2011.

[9]. Sun, J., X. Hu, G. Zhao, J. Wu, J. Wang, F. Chen, and X. Liao (2007), Characteristics of thin layer infrared drying of apple pomace with and without hot air pre-drying, Food Science and Technology International, Vol. 13(2), pp. 91-97.

[10]. Uretir, G. (1995), Modeling computer controlled apple drying processes, M.Sc. Thesis, METU, Turkey. 
[11]. Uretir, G., M. Ozilgen and S. Katnas (1996), Effects of velocity and temperature of air on the drying rate constants of apple cubes, Journal Food Engineering, Vol. 30, pp. 339-350.

[12]. Masoodi, F. A., and Chauhan, G. S. (1988). Use of apple pomace as a source of dietary fibre in wheat bread. Journal of Food Processing and Preservation. 22, 255-263. Mendoza E., Garcia M L., Casas C., and Selga.

[13]. Nowak, D. and P.P. Lewicki (2004), Infrared drying of apple slices, Innovative Food Science and Emerging Technologies, Vol. 5, pp. 353-360.

[14]. Ramaswamy, H. S. and N.H. Van Nieuwenhuijzen (2002), Evaluation and modelling of two-stage osmo-convective drying of apple slices, Drying Technology, Vol. 20(3), pp. 651-667.

[15]. Ranganna, S. (1986), Handbook of analysis and quality control for fruit and vegetable products. 2nd edition, Tata McGraw Hill Pub, New Delhi, India, pp. 441-496, 1112.

[16]. Shalani, R. \& Gupta, D.K. (2010) Utilization of pomace from apple processing industries: a review. Journal of Food Science and Technology, 47(4), 365-371.

[17]. Shishkina, Z.A., (1977) The importance of oxidation in bread making. Baker's Digest, 15: 39-43.

[18]. Sullivan, B., M. Howe, F.D. Schmalz and G.R. Astleford, 1940. The action of oxidizing agents in flour. Cereal Chem., 17: 507-20.

[19]. Toma R B; Orr P H; Appolonia B D; Dintzis F R.; Tabekhia M M. 1979. Physical and chemical properties of potato peel as a source of dietary fibre in bread. J. Food Sci., 44, 1403-1407, 1417.

[20]. Walter RH, Rao MA, Shermram RM, Cooley HJ (1985) Edible fibers from apple pomace. J Food Sci 50:747-749.

[21]. Wang HJ, Thomas RL (1989) Direct use of apple pomace in bakery products. J Food Sci 54: 618-620, 639

[22]. Anon (2004) Comprehensive study on processing of apple. Status of Apple Processing Industry in India. The Ministry of Food Processing Industries, Government of India. (Accessed on 01-04-2007).

[23]. Bates A.W., Roberts j.s (2001) The utilization of apple pomace as après aid in fruit juicing. In: IFT annual meeting - New Orleans , Louisiana: session 88E, Fruit and vegetable products : Processing . 8281. htm (Accessed on 01-04-2007). 